\section{Hyacinth Height Control Using Preplant Bulb Soaks of Flurprimidol}

\author{
Brian A. Krug, Brian E. Whipker ${ }^{1}$, and Ingram McCall
}

AdDitional INDEX words. Bonzi, paclobutrazol, Piccolo, plant growth regulators, Sumagic, Topflor, uniconazole

SUMMARY. Eight experiments were conducted to develop height control protocols for greenhouse-forced hyacinth (Hyacinthus orientalis) bulbs. 'Pink Pearl' hyacinth bulbs were treated with flurprimidol preplant bulb soaks to determine optimal timing of treatment, soak duration, quantity of bulbs that could be treated before the solution lost efficacy, bulb location of solution uptake, and if higher concentrations of flurprimidol can be used to overcome stretch that occurs with extended cold treatment. No difference in height control occurred when bulbs were soaked in flurprimidol the day of, 1 day before, or 7 days before potting; therefore, growers can treat bulbs up to 1 week before potting with no difference in height control. All preplant bulb soak durations of 1, 5, 10, 20, or $40 \mathrm{~min}$ controlled plant height. Any soak durations $\geq 1.3 \mathrm{~min}$ resulted in similar height control, which would provide growers with a flexible time frame of 2 to $40 \mathrm{~min}$ in which to soak the bulbs. When $1 \mathrm{~L}$ of $20 \mathrm{mg} \cdot \mathrm{L}^{-1}$ flurprimidol solution was used repeatedly over 20 batches of five bulbs, solution efficacy was similar from the first batch to the last batch, indicating the soak solution of flurprimidol can be used repeatedly without loss of efficacy. Soak solution temperature was also tested to determine its effect on flurprimidol and paclobutrazol uptake. Temperature of the soak solution $\left(8,16\right.$, or $\left.24^{\circ} \mathrm{C}\right)$ had no effect on flurprimidol and only at a temperature of $8{ }^{\circ} \mathrm{C}$ was the efficacy of paclobutrazol lower. Postharvest heights of 'Pink Pearl' hyacinths were similar whether only the top, bottom, or the entire bulb was soaked. Control provided by flurprimidol, paclobutrazol, or uniconazole preplant bulb soaks varied among the three hyacinth cultivars Delft Blue, Jan Bos, and Pink Pearl, so growers will have to conduct their own trials to determine optimal cultivar response to preplant bulb soaks. Also, 'Pacino' sunflowers (Helianthus annuus) were treated with residual soak solution of flurprimidol to determine if substrate drenches could be used as a disposal method. Fresh and residual solutions of flurprimidol $(1.18,2.37$, or $4.73 \mathrm{mg} /$ pot a.i.) applied to 'Pacino' sunflowers were similar in their efficacy of controlling height, which would enable growers to avoid disposal problems of residual soak solutions.

$\mathrm{P}$ lant growth regulators (PGRs) are often necessary for controlling greenhouse and postharvest height of hyacinths. Preplant bulb soaks have advantages over other application methods such as time and labor savings, accurate dosages, and reasonable costs; however, disposal of the residual soak solution may be problematic (Ranwala et al., 2002). Extensive research has been conducted to determine the optimal duration and timing of preplant bulb soaks of lilies (Lilium hybrids) using ancymidol (A-Rest; SePRO

Department of Horticulture Science, Box 7609, North Carolina State University, Raleigh, NC 27695-7609.

Use of trade names in this publication does not imply endorsement of products named nor criticism of similar ones not mentioned. Thanks to Berger for the root substrates, Scotts for the fertilizer, Dillen Products for the pots, and for grant support SePRO Co and Syngenta Co.

${ }^{1}$ To whom reprint requests should be addressed. E-mail address: brian_whipker@ncsu.edu
Corp., Carmel, Ind.). For example, Lewis and Lewis (1981) expressed concerns pertaining to uniform height control when using ancymidol preplant bulb soaks applied to lilies, caused by variability in dosage applied per bulb, which could occur as a function of bulb size and quantity of solution retained between the open scales.

Initial trials found flurprimidol bulb soaks were effective at controlling height of hyacinths (Krug et al., 2005b), oriental lilies (Krug et al., (Topflor; SePRO Corp.) preplant 2005a), and tulips (Tulipa sp.) (Krug et al., 2005c). However, current production guidelines do not include information about preplant bulb soaks, and this must be addressed to provide better guidelines. Therefore, the objectives of this research were to determine optimal timing of treatment, duration of treatment, efficacy over repeated use of flurprimidol preplant bulb soaks, effect of temperature on flurprimidol and paclobutrazol efficacy, effect of soak location on the bulb, effect of extended cold treatment on preplant bulb soaks of flurprimidol, cultivar response, and effective disposal of residual solutions.

\section{Materials and methods}

Cultural practices used for Expts. 1 through 7 were identical with the exception of PGR treatments. Upon arrival, bulbs were stored at $55^{\circ} \mathrm{F}$ until treatment initiation. Bulbs were treated with a preplant bulb soak and planted with one noncooled hyacinth bulb per 4-inch-diameter round plastic pot $(575$ $\mathrm{mL}$ ). The root substrate was Berger BM 6 (Berger Peat Moss, St. Modeste, Que.), which contained (by volume) $75 \%$ to $80 \%$ Canadian sphagnum peat and $20 \%$ to $25 \%$ perlite. For 10 weeks the cooler temperature set point was $41^{\circ} \mathrm{F}$. On 5 Jan. 2004 (Expts. 1-3, and 7), or 4 Jan. 2005 (Expts. 4-6), the cooler temperature set point was reduced to $34^{\circ} \mathrm{F}$ until 4 Feb. 2004 (Expts. 1-3, and 7), or 13 Feb. 2005 (Expts. 4-6), when the bulbs were removed from the cooler and allowed to acclimate overnight. Greenhouse forcing began 5 Feb. 2004 (Expts. $1-3$, and 7 ) or 14 Feb. 2005 (Expts. 4-6) with day/night temperature set points of $68 / 65^{\circ} \mathrm{F}$. Plants were forced under natural daylength. Anthesis date (one floret completely open), and total plant height at anthesis (measured from the pot rim to the uppermost part of the inflorescence) were recorded. Preplant PGR treatments were unique for each experiment (Expts. 1-7) as listed below.

\begin{tabular}{llll}
\hline $\begin{array}{l}\text { Units } \\
\text { To convert U.S. to SI, } \\
\text { multiply by }\end{array}$ & U.S. unit & SI unit & $\begin{array}{l}\text { To convert SI to U.S., } \\
\text { multiply by }\end{array}$ \\
\hline 29.5735 & $\mathrm{floz}$ & $\mathrm{mL}$ & 0.0338 \\
3.7854 & $\mathrm{gal}$ & $\mathrm{L}$ & 0.2642 \\
2.54 & inch $(\mathrm{es})$ & $\mathrm{cm}$ & 0.3937 \\
28,350 & $\mathrm{Oz}$ & $\mathrm{mg}$ & $3.5274 \times 10^{-5}$ \\
1 & $\mathrm{ppm}$ & $\mathrm{mg} \cdot \mathrm{L}^{-1}$ & 1 \\
$\left({ }^{\circ} \mathrm{F}-32\right) \div 1.8$ & ${ }^{\circ} \mathrm{F}$ & ${ }^{\circ} \mathrm{C}$ & $\left(1.8 \times{ }^{\circ} \mathrm{C}\right)+32$
\end{tabular}


EXPT. 1-Advanced SOAKING. 'Pink Pearl' hyacinth bulbs were soaked in flurprimidol $\left(20 \mathrm{mg} \cdot \mathrm{L}^{-1}\right)$ for $10 \mathrm{~min}$ and allowed to air dry in the greenhouse for 0,1 , or $7 \mathrm{~d}$ before potting. Treatments were applied 17, 23, or 24 Oct. 2003. Nontreated controls were also included. The experiment was a completely randomized design with six single-plant replications of four treatments.

Expt. 2-SoAK DURATion. 'Pink Pearl' hyacinth bulbs were soaked 23 Oct. 2003 in a solution of flurprimidol $\left(20 \mathrm{mg} \cdot \mathrm{L}^{-1}\right)$ for $1,5,10,20$, or $40 \mathrm{~min}$ before potting. Nontreated controls were also included. The experiment was a completely randomized design with six single-plant replications of six treatments.

EXPT. 3-FLURPRIMIDOL SOLUTION EFFICACY WITH REPEATED USE. Twenty batches of five 'Pink Pearl' bulbs were soaked 23 Oct. 2003, one batch at a time, for $10 \mathrm{~min}$ in $1 \mathrm{~L}$ of flurprimidol $\left(20 \mathrm{mg} \cdot \mathrm{L}^{-1}\right)$. Nontreated controls were also included. In addition to data described above, the soak solution volume was measured after soaking each batch. The experiment was a completely randomized design with five single-plant replications of 21 treatment batches.

Expt. 4-SOAK SOlution TEMPERATURE. Flurprimidol (30 or 60 $\mathrm{mg} \cdot \mathrm{L}^{-1}$ ) or paclobutrazol (Bonzi; Syngenta, Greensboro, N.C.) (150 or $300 \mathrm{mg} \cdot \mathrm{L}^{-1}$ ) preplant bulb soaks were applied for 2 min on 28 Oct. 2004. The temperature of the solution for each concentration was held constant at 8,16 , or $24{ }^{\circ} \mathrm{C}$ using a Blue $\mathrm{M}$ Magni-Whirl constant temperature bath (model MW-112CA-1; Blue M Electric Co., Blue Island, Ill.). Nontreated controls were also included for each temperature. The experiment was a completely randomized design with eight single-plant replications of 18 treatments.

EXPT. 5-EFFECTS OF SOAK LOCATION ON EFFICACY. Flurprimidol preplant bulb soaks were applied for $2 \mathrm{~min}$ at $30 \mathrm{or} 60 \mathrm{mg} \cdot \mathrm{L}^{-1}$ on 28 Oct. 2004. The temperature of the solution was held constant at $24^{\circ} \mathrm{C}$ using a Blue M Magni-Whirl constant temperature bath (model MW-112CA-1). Three different soak treatments were applied for each concentration: the entire bulb, the top $50 \%$ of the bulb, or the bottom $50 \%$ of the bulb. Nontreated controls were also included. The experiment was a completely randomized design with eight single-plant replications of seven treatments.

EXPT. 6-EXTENDED COLD TREATMENT. Flurprimidol preplant bulb soaks were applied for 2 min at 25 or $37.5 \mathrm{mg} \cdot \mathrm{L}^{-1}$ on $28 \mathrm{Oct}$. 2004. The experiment was a completely randomized design with eight single-plant replications of nine treatments, including nontreated controls. Eight replications of each treatment were removed from the cooler to begin greenhouse forcing on each of the three dates: 14 Feb., 14 Mar., and 14 Apr.

EXPT. 7-Cultivar Response. The following treatments were applied to 'Delft Blue', 'Jan Bos', and 'Pink Pearl' on 24 Oct. 2003 as a preplant soak for $10 \mathrm{~min}$ : flurprimidol at $10,15,20,25,30,35$, or 40 $\mathrm{mg} \cdot \mathrm{L}^{-1}$; paclobutrazol (Piccolo; Fine Agrochemical, Whittington, U.K.) at 100 or $200 \mathrm{mg} \cdot \mathrm{L}^{-1}$; or uniconazole at $25 \mathrm{or} 30 \mathrm{mg} \cdot \mathrm{L}^{-1}$; and a nontreated control. Data were recorded as stated above. The experiment was a completely randomized design with six single-plant replications of each of the 12 treatments for each of the three cultivars.

Data analysis. Data for Expts. 1 through 7 were subjected to analysis of variance (ANOVA) using general linear model procedure in SAS (SAS Institute, Cary, N.C.). Anthesis and postharvest plant height values were regressed using PROC REG procedure to determine the best-fit, linear or quadratic, model. Terms of the model were evaluated for significance based on a comparison of $F$ values at $\alpha=$ 0.05 . PROC NLIN in SAS, as modified by Cox (1992), was used to calculate linear-plateau functions (model IV) relating anthesis and postharvest plant height to preplant bulb soaks of flurprimidol. The quadratic and the linear-plateau models were compared to determine the best fit based on $r^{2}$ values. Means were also compared using orthogonal contrasts.

Postharvest-EXPts. 1 to 7. Four plants, randomly selected from each treatment, were placed in a postharvest room with the temperature set point at $68^{\circ} \mathrm{F}$ after anthesis. Fluorescent lamps provided a daily 12 -h photoperiod at 24 to $75 \mu \mathrm{mol} \cdot \mathrm{m}^{-2} \cdot \mathrm{s}^{-1}$. Plant height (measured from the top of the pot rim to the uppermost part of the inflorescence) was recorded 10 to $13 \mathrm{~d}$ after anthesis.
EXPT. 8-Disposal of Residual SOAK SOLUTIONS. 'Pacino' sunflower seeds were sown into cell packs $(3 \times 3$ $\times 4 \mathrm{~cm}$ ) on 24 Sept. 2003; seedlings were transplanted into 6-inch-diameter round plastic pots with a volume of 1.9 L on 10 Oct. 2003. The root substrate for cell packs and pots was Berger BM 6 , which contained (by volume) $75 \%$ to $80 \%$ Canadian sphagnum peat and $20 \%$ to $25 \%$ perlite. Greenhouse day/night temperature set points were $68 / 64^{\circ} \mathrm{F}$. The plants were grown under natural daylength.

Flurprimidol substrate drenches were applied to 'Pacino' sunflower plants with $4 \mathrm{fl} \mathrm{oz}$ of solution per pot. Drenches were made with either fresh or residual solution at $1.18,2.37$, or $4.73 \mathrm{mg} /$ pot a.i. (approximately 10,20 , or $\left.40 \mathrm{mg} \cdot \mathrm{L}^{-1}\right)$. Nontreated controls were also included. Fresh solution was mixed immediately before treatments and residual solution was obtained after use as a preplant bulb soak where 84 bulbs [54 tulips and 30 narcissus (Narcissus pseudonarcissus)] were soaked in $1 \mathrm{~L}$ of solution. Anthesis date (one flower completely open), plant height (measured from the soil line to the uppermost part of the inflorescence), and plant diameter (measured at the widest dimension and turned $90^{\circ}$, and averaged) for sunflowers were recorded. The experiment was a completely randomized design with six single-plant replications of seven treatments.

Plant height, plant diameter, and flower date values in Expt. 8 were regressed using PROC REG procedures in SAS to determine the best fit, linear or quadratic, model. Variables in the model were PGR concentration (concn) and indicator variables for solution type (soln), with the full model as follows:

$$
\begin{aligned}
& \text { Concentration }_{i} \\
& \quad=\beta_{0}+\beta_{1} \operatorname{soln}_{2}+\beta_{2} \text { concn } \\
& \quad+\beta_{3} \operatorname{concn}^{2} \operatorname{soln}_{2}+\beta_{4} \text { concn }^{2} \\
& \quad+\beta_{5} \operatorname{concn}^{2} \times \operatorname{soln}_{2}
\end{aligned}
$$

where concentration ${ }_{i}=$ PGR concentration $\left(0,10,20\right.$, or $\left.40 \mathrm{mg} \cdot \mathrm{L}^{-1}\right) ; i=$ variable being regressed (plant height or diameter); $\operatorname{soln}_{2}=1$ if the PGR solution was reused, 0 otherwise (when $\operatorname{soln}_{2}=0$, then soln $=$ unused solution); $\beta_{k}=$ estimated coefficients $(k=0$ to $5)$. Terms of the model were judged to be significant or nonsignificant and included in the final model based on a comparison of $F$ values at $\alpha=0.05$. 
Table 1. Plant heights of 'Pink Pearl' hyacinth at anthesis and postharvest ( $13 \mathrm{~d}$ after anthesis) when treated with preplant bulb soaks of flurprimidol at $20 \mathrm{mg} \cdot \mathrm{L}^{-1}(\mathrm{ppm})$ the same day of potting, $1 \mathrm{~d}$, or $7 \mathrm{~d}$ before potting.

\begin{tabular}{|c|c|c|}
\hline & \multicolumn{2}{|c|}{ Plant ht $(\mathrm{cm})^{\mathrm{z}}$} \\
\hline & Anthesis & Postharvest \\
\hline \multicolumn{3}{|l|}{ Bulb treatment } \\
\hline Control (nontreated) & $14.6^{y}$ & $25.0^{\mathrm{x}}$ \\
\hline Same day & 12.0 & 20.8 \\
\hline $1 \mathrm{~d}$ & 11.4 & 20.9 \\
\hline $7 \mathrm{~d}$ & 12.8 & 20.8 \\
\hline \multicolumn{3}{|l|}{ Contrasts } \\
\hline Control (0 soak) vs. any soak timing & * & $* * *$ \\
\hline Same day vs. $1 \mathrm{~d}$ & NS & NS \\
\hline Same day vs. $7 \mathrm{~d}$ & NS & NS \\
\hline
\end{tabular}

\section{Results and discussion}

EXPT. 1-ADVANCED SOAKING. Height of 'Pink Pearl' hyacinths, at anthesis and postharvest evaluation, were similar when preplant bulb soaks of flurprimidol at $20 \mathrm{mg} \cdot \mathrm{L}^{-1}$ were applied the day of potting, $1 \mathrm{~d}$ before, or $7 \mathrm{~d}$ before potting (Table 1). An application window of up to $7 \mathrm{~d}$ before planting allows growers to treat a large quantity of hyacinth bulbs at one time and pot the plants when labor is available over a 7 -d period.

EXPT. 2-SoAK DURATION. Plant height of 'Pink Pearl' hyacinths at anthesis and postharvest evaluation were significantly $(P \leq 0.05)$ shorter than the nontreated controls using preplant bulb soaks of flurprimidol ( 20 $\left.\mathrm{mg} \cdot \mathrm{L}^{-1}\right)$ at any time duration trialed $(\mathrm{l}$, $5,10,20$, or $40 \mathrm{~min}$ ) (Fig. 1). At the end of the postharvest evaluation, the response was best fit to a linear-plateau model that resulted in the smallest plants $(18.7 \mathrm{~cm}$ tall, $25 \%$ shorter than the nontreated controls) when bulbs were soaked for $1.3 \mathrm{~min}$. No further increases in height control occurred at soak durations $\geq 1.3$ min (Fig. 1). According to Krug et al. (2005b), flurprimidol soaks at $25 \mathrm{mg} \cdot \mathrm{L}^{-1}$ for 10 min were recommended for hyacinth, and De Hertogh (1996a) suggested using 1-h paclobutrazol soaks for height control of freesia. With shorter soak durations providing suitable height control, growers will be able to save time in the application of flurprimidol preplant bulb soaks.

EXPT. 3-FLURPRIMIDOL SOLUTION EFFICACY WITH REPEATED USE. 'Pink Pearl' hyacinth bulbs were sig- nificantly $(P \leq 0.05)$ shorter than the nontreated controls as a result of soaking batches of bulbs over time (data not presented), with the exception of bulb batches 13 and 18. It is unclear why these two batches were not significantly different than the nontreated controls. The soak solution utilized by each batch ranged from 20 to $40 \mathrm{~mL}$ ( 4 to $8 \mathrm{~mL}$ per bulb). Batches 13 and 18 absorbed 35 and $30 \mathrm{~mL}$ ( 7 to $6 \mathrm{~mL}$ per bulb) of solution, respectively, so the absence of height control in those batches was not due to lack of PGR utilization. Removal of tunics of tulip bulbs during storage increases respiration (De Hertogh and LeNard, 1993). From this information it could be deduced that the presence of a tunic could limit uptake of a PGR solution. Although the

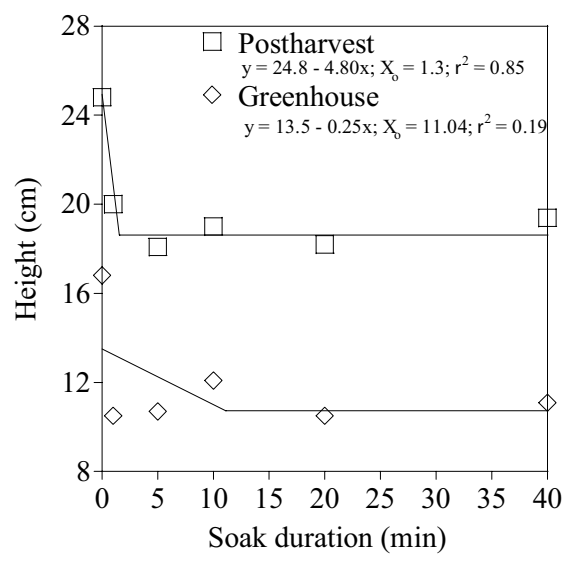

Fig. 1. Plant heights of 'Pink Pearl' hyacinth at greenhouse forcing (anthesis) and postharvest (13 d later) when treated with preplant bulb soaks of flurprimidol at $20 \mathrm{mg} \cdot \mathrm{L}^{-1}(\mathrm{ppm})$ for $1,5,10,20$, or $40 \mathrm{~min}(1 \mathrm{~cm}=$ 0.3937 inch). hyacinth tunics were not inspected, the bulbs in batches 13 and 18 may have possessed thicker tunic layers that hindered PGR uptake. Also, as there were 20 treatments it is possible that these two sets were merely outliers. Regardless, plant height was similar between the first and last batch of bulbs (data not presented). Repeated use of a 1-L solution of flurprimidol over 20 batches of hyacinth bulbs did not diminish the efficacy of the solution. Each batch of five bulbs absorbed on average 30.5 $\mathrm{mL}$ of solution (data not presented). At this rate of utilization, only $390 \mathrm{~mL}$ of solution remained at the end of batch 20 , which was the minimum volume needed to completely submerge five bulbs. Therefore, the solution would need to be replenished prior to any possible loss of efficacy. Similar findings were reported when hybrid lilies were soaked repeatedly in paclobutrazol (Ranwala et al., 2005). This utilization of the PGR soak solution would also decrease the amount of residual solution requiring disposal.

EXPT. 4-SOAK SOLUTION TEMPERATURe. Preplant bulb soaks of flurprimidol $\left(0,30\right.$, or $\left.60 \mathrm{mg} \cdot \mathrm{L}^{-1}\right)$ at any temperature $\left(8,16\right.$, or $\left.24^{\circ} \mathrm{C}\right)$ resulted in similar control of height at anthesis and postharvest evaluation, regardless of concentration (Table 2). The efficacy of paclobutrazol preplant bulb soaks at $150 \mathrm{mg} \cdot \mathrm{L}^{-1}$ was lower when the soak solution temperature was $8{ }^{\circ} \mathrm{C}$, but at $300 \mathrm{mg} \cdot \mathrm{L}^{-1}$ height during postharvest evaluation was similar and the effects of solution temperature were overcome (Table 3 ). It is unlikely that growers would notice the negative effects of solution temperature on the efficacy of the paclobutrazol preplant bulb soaks, as $8{ }^{\circ} \mathrm{C}$ is lower than the tap water temperature at most locations. However, growers should monitor water temperature; if tap water temperature is $\leq 8^{\circ} \mathrm{C}$, adjustments should be made to increase the water temperature to $16{ }^{\circ} \mathrm{C}$.

EXPT. 5-EFFECTS OF SOAK LOCATION ON EFFICACY. At anthesis, the efficacy of flurprimidol preplant bulb soaks at $30 \mathrm{mg} \cdot \mathrm{L}^{-1}$ was lower when applied only to the top of the bulb when compared to applications made to the bottom or the entire bulb (Table 4 ). With a concentration of $60 \mathrm{mg} \cdot \mathrm{L}^{-1}$, the efficacy of flurprimidol was lower when applied to the top of the bulb as compared to only the bottom. It is possible that the lower efficacy observed 
can be attributed to a smaller amount of surface area in contact with the soak solution. However, height control is most important during postharvest evaluation. There was no loss of flurprimidol efficacy at any soak location or concentration during the postharvest evaluation. Growers can be confident that the height control provided by flurprimidol will not be affected during postharvest if bulbs are not completely submerged in the solution throughout the duration of the soak.

EXPT. 6-EXTENDED COLD TREATMENT. When bulbs were held for either 15 weeks of cold treatment or for 23 weeks, a concentration $\geq 25 \mathrm{mg} \cdot \mathrm{L}^{-1}$ resulted in significantly $(P \leq 0.05)$ shorter plants than the nontreated controls at anthesis and postharvest evaluations (Table 5 ). However, when the bulbs were held for 19 weeks of cold treatment, no concentration resulted in plants shorter than the nontreated controls at anthesis or postharvest evaluations. Correct cooling requirements are important when producing other bulb crops, such as tulips, to ensure stem lengths are not excessive (De Hertogh, 1996b). This also appears to apply to hyacinth because regardless of PGR concentration, as the length of the cold treatment was extended, plant height also increased. Growers can extend the sales of hyacinths by holding bulbs in the cooler for extra time; however, the use of preplant bulb soaks of flurprimidol at higher concentrations $\left(37.5 \mathrm{mg} \cdot \mathrm{L}^{-1}\right)$ to ensure a quality crop over this extended time had little effect. Growers will observe more desirable results by staggering planting time and using the recommended cold treatment schedules. Concentrations $>37.5 \mathrm{mg} \cdot \mathrm{L}^{-1}$ should also be investigated.

Expt. 7. Cultivar Response. 'Delft Blue'. No control of plant height during greenhouse forcing was provided at the concentrations of flurprimidol, paclobutrazol, and uniconazole concentrations tested. Anthesis was significantly delayed ( $P \leq$ 0.05 ) by flurprimidol concentrations of $35 \mathrm{mg} \cdot \mathrm{L}^{-1}$ and uniconazole at 25 $\mathrm{mg} \cdot \mathrm{L}^{-1}$ by 1.3 and $1.2 \mathrm{~d}$, respectively, compared to the nontreated controls (data not presented), but this would not be considered excessive by commercial standards (M. Bell, personal communication).

During postharvest evaluation, preplant soaks of flurprimidol $\geq 10$

Table 2. Plant heights of 'Pink Pearl' hyacinth at anthesis (Anth.) and postharvest $(\mathrm{PH})\left(10 \mathrm{~d}\right.$ after anthesis) when soaked in 0,30 , or $60 \mathrm{mg} \cdot \mathrm{L}^{-1}(\mathrm{ppm})$ flurprimidol solutions at 8,16 , or $24^{\circ} \mathrm{C}$.

\begin{tabular}{|c|c|c|c|c|c|c|}
\hline & \multicolumn{6}{|c|}{ Plant ht $(\mathrm{cm})^{\mathrm{z}}$} \\
\hline & \multicolumn{2}{|c|}{$0 \mathrm{mg} \cdot \mathrm{L}^{-1}$} & \multicolumn{2}{|c|}{$30 \mathrm{mg} \cdot \mathrm{L}^{-1}$} & \multicolumn{2}{|c|}{$60 \mathrm{mg} \cdot \mathrm{L}^{-1}$} \\
\hline & Anth. & $\mathrm{PH}$ & Anth. & $\mathrm{PH}$ & Anth. & $\mathrm{PH}$ \\
\hline \multicolumn{7}{|c|}{ Temperature $\left({ }^{\circ} \mathrm{C}\right)^{\mathrm{z}}$} \\
\hline 8 & 11.4 & 19.4 & 10.4 & 16.6 & 9.1 & 14.8 \\
\hline 16 & 13.2 & 20.3 & 11.2 & 16.7 & 10.4 & 15.3 \\
\hline 24 & 11.7 & 18.4 & 11.3 & 17.5 & 9.7 & 15.1 \\
\hline \multicolumn{7}{|l|}{ Contrasts } \\
\hline 8 vs. 16 & NS & NS & NS & NS & NS & NS \\
\hline 8 vs. 24 & NS & NS & NS & NS & NS & NS \\
\hline 16 vs. 24 & NS & NS & NS & NS & NS & NS \\
\hline
\end{tabular}

Table 3. Plant heights of 'Pink Pearl' hyacinth at anthesis (Anth.) and postharvest $(\mathrm{PH})\left(10 \mathrm{~d}\right.$ after anthesis) when soaked in 0,150 , or $300 \mathrm{mg} \cdot \mathrm{L}^{-1}$ $(\mathrm{ppm})$ paclobutrazol solutions at 8,16 , or $24^{\circ} \mathrm{C}$.

\begin{tabular}{|c|c|c|c|c|c|c|}
\hline & \multicolumn{6}{|c|}{ Plant ht $(\mathrm{cm})^{\mathrm{z}}$} \\
\hline & \multicolumn{2}{|c|}{$0 \mathrm{mg} \cdot \mathrm{L}^{-1}$} & \multicolumn{2}{|c|}{$150 \mathrm{mg} \cdot \mathrm{L}^{-1}$} & \multicolumn{2}{|c|}{$300 \mathrm{mg} \cdot \mathrm{L}^{-1}$} \\
\hline & Anth. & $\mathrm{PH}$ & Anth. & $\mathrm{PH}$ & Anth. & $\mathrm{PH}$ \\
\hline \multicolumn{7}{|c|}{ Temperature $\left({ }^{\circ} \mathrm{C}\right)^{\mathrm{z}}$} \\
\hline 8 & 12.7 & 19.1 & 12.4 & 17.7 & 10.9 & 15.8 \\
\hline 16 & 12.9 & 19.5 & 10.9 & 15.5 & 9.6 & 14.2 \\
\hline 24 & 12.6 & 20.3 & 10.7 & 15.2 & 9.8 & 14.0 \\
\hline \multicolumn{7}{|l|}{ Contrasts } \\
\hline 8 vs. 16 & NS & NS & NS & * & * & NS \\
\hline 8 vs. 24 & NS & NS & * & * & NS & NS \\
\hline 16 vs. 24 & NS & NS & NS & NS & NS & NS \\
\hline
\end{tabular}

${ }^{\mathrm{z}}\left(1.8 \times{ }^{\circ} \mathrm{C}\right)+32={ }^{\circ} \mathrm{F} ; 1 \mathrm{~cm}=0.3937$ inch.

Ns, * Nonsignificant or significant at $P \leq 0.05$

Table 4. Plant heights of 'Pink Pearl' hyacinth at anthesis (Anth.) and postharvest $(\mathrm{PH})$ (10 d after anthesis) when flurprimidol preplant bulb soaks were applied to the entire bulb, the top of the bulb, or the bottom of the bulb.

\begin{tabular}{|c|c|c|c|c|c|c|}
\hline & \multicolumn{6}{|c|}{ Plant ht $(\mathrm{cm})^{\mathrm{z}}$} \\
\hline & \multicolumn{2}{|c|}{$0 \mathrm{mg} \cdot \mathrm{L}^{-1}$} & \multicolumn{2}{|c|}{$30 \mathrm{mg} \cdot \mathrm{L}^{-1}$} & \multicolumn{2}{|c|}{$60 \mathrm{mg} \cdot \mathrm{L}^{-1}$} \\
\hline & Anth. & $\mathrm{PH}$ & Anth. & $\mathrm{PH}$ & Anth. & $\mathbf{P H}$ \\
\hline Bulb soak location & 11.1 & 17.1 & 9.5 & 15.7 & 9.6 & 14.5 \\
\hline Bottom & 10.7 & 17.8 & 9.4 & 15.2 & 8.4 & 14.8 \\
\hline Top & 12.0 & 19.0 & 11.7 & 16.4 & 11.0 & 16.0 \\
\hline \multicolumn{7}{|l|}{ Contrasts } \\
\hline Entire vs. Bottom & NS & NS & NS & NS & NS & NS \\
\hline Entire vs. Top & NS & NS & * & NS & NS & NS \\
\hline Bottom vs. Top & NS & NS & * & NS & * & NS \\
\hline
\end{tabular}

${ }^{\mathrm{z}} 1 \mathrm{~cm}=0.3937$ inch.

Ns, ${ }^{*}$ Nonsignificant or significant at $P \leq 0.05$.

$\mathrm{mg} \cdot \mathrm{L}^{-1}$ controlled plant height, and resulted in plants $\geq 3 \%$ shorter than the nontreated controls (Fig. 2A). Paclobutrazol controlled postharvest height at concentrations $\geq 100 \mathrm{mg} \cdot \mathrm{L}^{-1}$ and resulted in plants $\geq 12 \%$ shorter than the nontreated controls. Uniconazole at $30 \mathrm{mg} \cdot \mathrm{L}^{-1}$ controlled height during the postharvest evaluation and resulted in plants $25.9 \mathrm{~cm}$ tall, which were $8 \%$ shorter than the nontreated controls. Based on regression analysis (Fig. 2A) flurprimidol concentrations of 34.3 and $15.7 \mathrm{mg} \cdot \mathrm{L}^{-1}$ would be required to obtain similar control as paclobutrazol at $200 \mathrm{mg} \cdot \mathrm{L}^{-1}$ and uniconazole at $30 \mathrm{mg} \cdot \mathrm{L}^{-1}$, respectively, during the postharvest evaluation. 
Table 5. Plant heights of 'Pink Pearl' hyacinth at anthesis (Anth.) and postharvest $(\mathrm{PH})(10 \mathrm{~d}$ after anthesis) when bulbs were treated with flurprimidol preplant soaks and subsequently received cold treatment, for 15, 19, or 23 weeks.

\begin{tabular}{|c|c|c|c|c|c|c|}
\hline & \multicolumn{6}{|c|}{ Plant ht $(\mathrm{cm})^{\mathrm{z}}$} \\
\hline & \multicolumn{2}{|c|}{15 weeks } & \multicolumn{2}{|c|}{19 weeks } & \multicolumn{2}{|c|}{23 weeks } \\
\hline & Anth. & PH & Anth. & PH & Anth. & $\mathrm{PH}$ \\
\hline $\begin{array}{l}\text { Flurprimidol concn } \\
{\left[\mathrm{mg} \cdot \mathrm{L}^{-1}(\mathrm{ppm})\right]}\end{array}$ & 12.2 & 17.7 & 13.6 & 19.5 & 15.3 & 21.3 \\
\hline 25 & 10.4 & 15.6 & 13.2 & 17.0 & 12.9 & 18.5 \\
\hline 37.5 & 10.3 & 15.4 & 12.9 & 17.3 & 11.7 & 17.4 \\
\hline \multicolumn{7}{|l|}{ Contrasts } \\
\hline 0 vs. 25 & * & * & NS & NS & * & * \\
\hline 0 vs. 37.5 & * & * & NS & NS & * & * \\
\hline 25 vs. 37.5 & NS & NS & NS & NS & NS & NS \\
\hline
\end{tabular}

$1 \mathrm{~cm}=0.3937$ inch.

ss, *Nonsignificant or significant at $P \leq 0.05$.

'JAN Bos'. During greenhouse forcing, hyacinth plants were $\geq 4 \%$ shorter than the nontreated controls at concentrations $\geq 10 \mathrm{mg} \cdot \mathrm{L}^{-1}$ flurprimidol (Fig. 2B). Plant height was controlled at a paclobutrazol concentration of $100 \mathrm{mg} \cdot \mathrm{L}^{-1}$, and resulted in plants $12.3 \mathrm{~cm}$ tall, which were $19 \%$ shorter than the nontreated controls. Concentrations of uniconazole $\geq 25$ $\mathrm{mg} \cdot \mathrm{L}^{-1}$ resulted in plants $\geq 15 \%$ shorter than the nontreated controls. Anthesis was delayed by $1.3 \mathrm{~d}(P \leq 0.05)$ only with uniconazole at $25 \mathrm{mg} \cdot \mathrm{L}^{-1}$ (data not presented), which would not be considered excessive by commercial standards.

During postharvest evaluation, height was controlled by flurprimidol concentrations $\geq 10 \mathrm{mg} \cdot \mathrm{L}^{-1}$ and resulted in plants $\geq 4 \%$ shorter than the nontreated controls. Concentrations of paclobutrazol $\geq 100 \mathrm{mg} \cdot \mathrm{L}^{-1}$ and uniconazole $\geq 25 \mathrm{mg} \cdot \mathrm{L}^{-1}$ resulted in plants $\geq 18 \%$ and $\geq 13 \%$ shorter, respectively, than the nontreated controls. Based on regression analysis (Fig. 2B), flurprimidol concentrations of 32.7 and 20.0 $\mathrm{mg} \cdot \mathrm{L}^{-1}$ would be required to obtain similar control as paclobutrazol at 200 $\mathrm{mg} \cdot \mathrm{L}^{-1}$ and uniconazole at $30 \mathrm{mg} \cdot \mathrm{L}^{-1}$, respectively, during the postharvest evaluation.

'Pink Pearl'. Flurprimidol at concentrations $\geq 15 \mathrm{mg} \cdot \mathrm{L}^{-1}$ controlled plant height $\geq 15 \%$, as compared to the nontreated controls (Fig. 2C). Paclobutrazol controlled plant height at concentrations $\geq 100 \mathrm{mg} \cdot \mathrm{L}^{-1}$ and resulted in plants $\geq 17 \%$ shorter than the nontreated controls. Uniconazole at $25 \mathrm{mg} \cdot \mathrm{L}^{-1}$ resulted in plants 12.3 $\mathrm{cm}$ tall, which were $12 \%$ shorter than the nontreated controls. Flurprimidol at $40 \mathrm{mg} \cdot \mathrm{L}^{-1}$ and uniconazole at 25 $\mathrm{mg} \cdot \mathrm{L}^{-1}$ delayed anthesis by 1.6 and $2.3 \mathrm{~d}(P \leq 0.05)$, respectively (data not presented), which would not be considered excessive by commercial standards.

Concentrations of flurprimidol $\geq 10 \mathrm{mg} \cdot \mathrm{L}^{-1}$ controlled plant height during postharvest and resulted in plants $\geq 15 \%$ shorter than the nontreated controls. Paclobutrazol concentrations $\geq 100 \mathrm{mg} \cdot \mathrm{L}^{-1}$ and uniconazole concentrations $\geq 25 \mathrm{mg} \cdot \mathrm{L}^{-1}$ resulted in plants $\geq 26 \%$ and $\geq 21 \%$ shorter, respectively, than the nontreated controls. During the postharvest evaluation, based on regression analysis (Fig. 2C), a concentration of flurprimidol at $16.0 \mathrm{mg} \cdot \mathrm{L}^{-1}$ would be required to obtain similar control as paclobutrazol at $200 \mathrm{mg} \cdot \mathrm{L}^{-1}$; and a concentration of flurprimidol at $15.6 \mathrm{mg} \cdot \mathrm{L}^{-1}$ would be required to obtain similar control as uniconazole at $30 \mathrm{mg} \cdot \mathrm{L}^{-1}$.

During greenhouse forcing, preplant bulb soaks of flurprimidol did not control height on 'Delft Blue', but were effective for 'Jan Bos' and 'Pink Pearl' at concentrations of 10 and $15 \mathrm{mg} \cdot \mathrm{L}^{-1}$, respectively. Preplant bulb soaks of flurprimidol at 25 $\mathrm{mg} \cdot \mathrm{L}^{-1}$ applied to 'Delft Blue', 'Jan Bos', and 'Pink Pearl' resulted in 7\%, $10 \%$, and $27 \%$ shorter plants than the nontreated controls at the postharvest evaluation. During previous trials the lowest concentration used was 25 $\mathrm{mg} \cdot \mathrm{L}^{-1}$ on 'Anna Marie' hyacinths, which resulted in plants $10 \%$ shorter than the nontreated controls at the time of postharvest evaluation (Krug et al., 2005b). The response of 'Anna Marie' in the previous trial and 'Jan Bos' during this experiment to preplant bulb soaks of flurprimidol were similar; however, flurprimidol had greater ef-
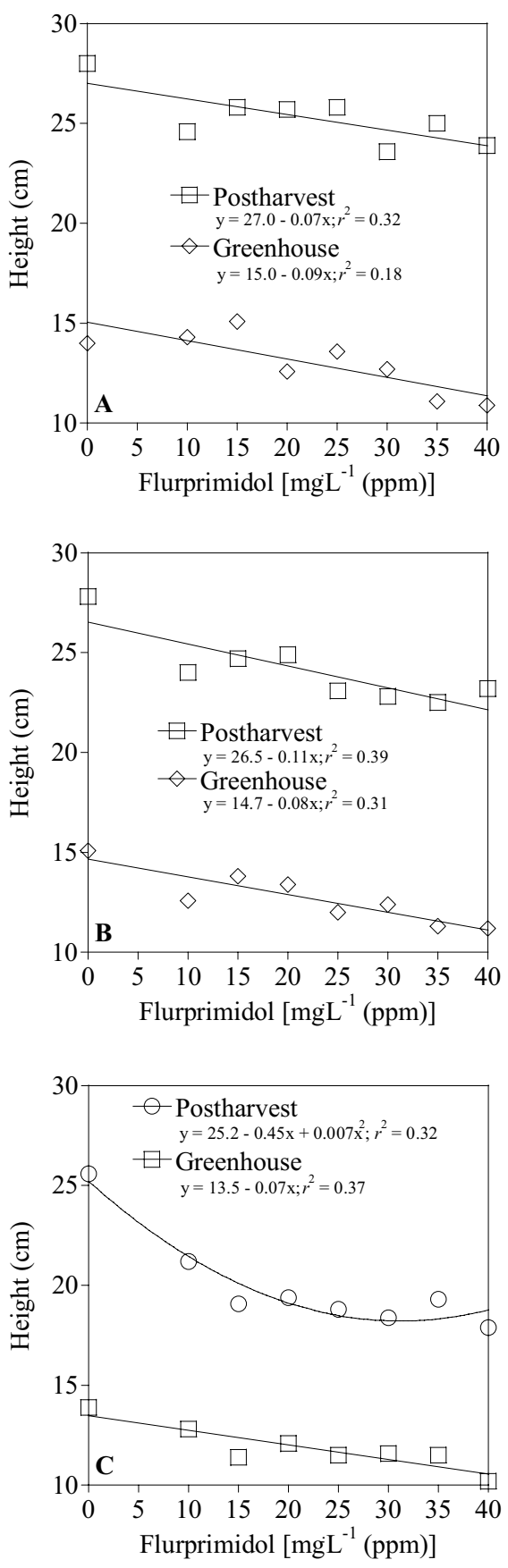

Fig. 2. Effects of preplant bulb soaks of flurprimidol on plant height at anthesis and during postharvest evaluation of (A) 'Delft Blue', (B) 'Jan Bos', and $(\mathrm{C})$ 'Pink Pearl' hyacinth plant height $(1 \mathrm{~cm}=0.3937$ inch $)$.

ficacy on 'Pink Pearl' and had less efficacy on 'Delft Blue'. Cultivar response variations to PGRs have also been reported with sunflower (Whipker and McCall, 2000), lily cultivars (Ranwala et al., 2002), and tulip cultivars ( Krug, 2004). Therefore, growers should conduct on-site trials to determine the optimal concentrations for other cultivars of hyacinth. 

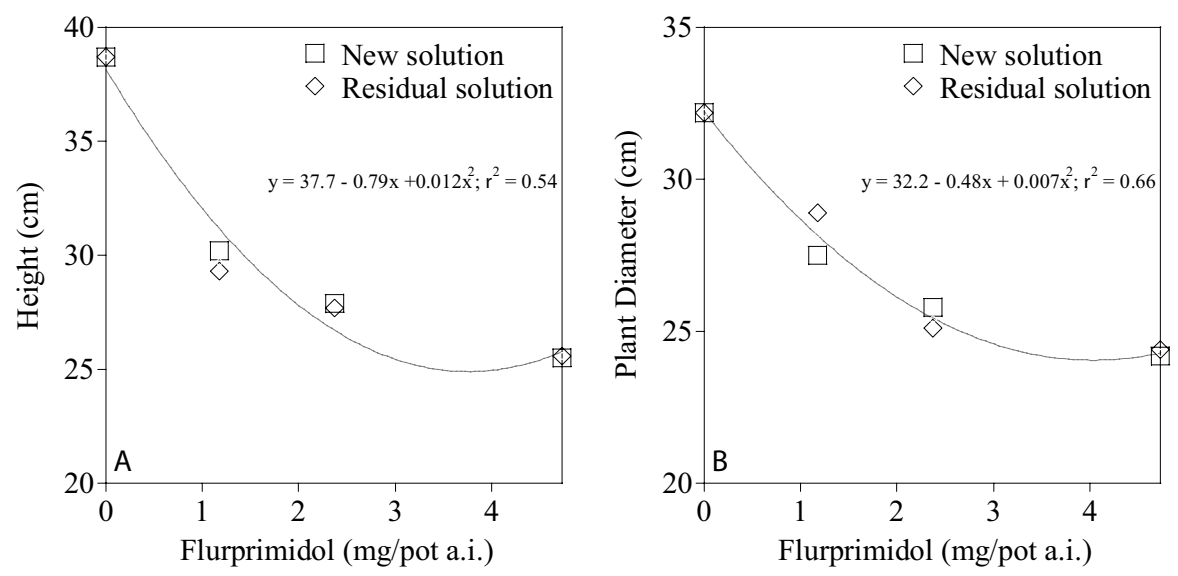

Fig 3. Effects of new or residual drench solutions of flurprimidol on 'Pacino' sunflower $(A)$ height and $(B)$ diameter $(1 \mathrm{~cm}=0.3937$ inch; $1 \mathrm{mg}=3.5274 \times$ $\left.10^{-5} \mathrm{oz}\right)$.

EXPT. 8-DisPosAl OF RESIDUAL SOAK SOLuTIONs. Plant height and diameter of sunflower 'Pacino' was not significantly $(P \leq 0.05)$ influenced by either PGR substrate drench solution (fresh or residual) and the data were pooled by concentration. Anthesis was not delayed by any treatment (data not presented). There were significant $(P \leq$ 0.05 ) quadratic relationships between the dose and both total plant height and diameters for 'Pacino' sunflowers (Fig. $3 \mathrm{~A}$ and $\mathrm{B}$ ). Using the residual solution from preplant bulb soaks of flurprimidol as a substrate drench on 'Pacino' sunflowers provided similar control as the fresh drench solution. This evidence illustrates that residual solutions can be further utilized as an effective substrate drench on other greenhouse crops for a suitable alternative disposal. Further studies need to be conducted to evaluate bulbs other than tulips and narcissus to determine the effects of the shipping material (peat vs. sawdust), as well as greater numbers of bulbs soaked before the residual solution is used as a substrate drench. As reported above with Expt. 3, it is possible that after repeated use, there will be little solution in need of disposal due to utilization by the bulbs.

\section{Conclusions}

Analysis of experimental results suggests that use of preplant bulb soaks of flurprimidol is a suitable height control option to prevent postharvest stretch of hyacinths. Growers have the flexibility of treating either the day of or up to $7 \mathrm{~d}$ in advance of potting; can soak the bulbs anywhere between 2 and $40 \mathrm{~min}$; and re-use the solution with at least 100 bulbs/L (at which time the solution will need to be replenished) and still achieve a similar degree of height control. Solution temperature does not need to be monitored (if tap water temperature is $\geq 16^{\circ} \mathrm{C}$ ) and adequate height control is provided whether the entire bulb, just the top, or just the bottom of the bulb is submerged for the full duration of the soak. Acceptable height control was not obtained with higher concentrations of flurprimidol when bulbs were held for extended cold treatment before forcing; therefore, staggered planting dates should be used. Based on the results, cultivar differences exist among hyacinths when flurprimidol preplant bulb soaks are used. Furthermore, the problem of disposing the residual soak the solution as a substrate drench on another crop. Flurprimidol preplant bulb soaks offer growers an alternative treatment method with flexibility for height control on bulb crops. Growers should conduct on-site trials to determine the optimal soak duration for individual species. solution can be overcome by applying

\section{Literature cited}

Cox, F.R. 1992. Range in soil phosphorus critical levels with time. Soil Sci. Soc. Amer. J. 56:1504-1509.

De Hertogh, A. 1996a. Freesia potted plants, p. C65-72. Holland bulb forcer's guide. Intl. Bulb Ctr., Hillegom, The Netherlands.

De Hertogh, A. 1996b. Potted tulips (Tulipa), p. Bl-24. Holland bulb forcer's guide. Intl. Bulb Ctr., Hillegom, The Netherlands.

De Hertogh, A. and M. LeNard. 1993. Botanical aspects of flower bulbs, p. 7-20. In: A. DeHertogh and M. LeNard (eds.). The physiology of flower bulbs. Elsevier, Amsterdam, The Netherlands.

Krug, B.A. 2004. The chemical growth regulation of bulb crops using flurprimidol as foliar sprays, substrate drenches, and preplant bulb soaks. MS thesis, N.C. State Univ., Raleigh.

Krug, B.A., B.E. Whipker, and I. McCall. 2005a. Flurprimidol is effective at controlling height of 'Star Gazer' oriental lily. HortTechnology 15:373-376.

Krug, B.A., B.E. Whipker, I. McCall, and J.M. Dole. 2005b. Comparison of flurprimidol to ethephon, paclobutrazol, and uniconazole for hyacinth height control. HortTechnology 15:1-3.

Krug, B.A., B.E. Whipker, I. McCall, and J.M. Dole. 2005c. Comparison of flurprimidol to ancymidol, paclobutrazol, uniconazole for tulip height control. HortTechnology 15:370-373.

Lewis, A.J. and J.S. Lewis. 1981. Improving ancymidol efficiency for height control of easter lily. HortScience 16:89-90.

Ranwala, A.P., G. Legnani, M. Reitmeier, B.B. Stewart, and W.B. Miller. 2002. Efficacy of plant growth retardants as preplant bulb dips for height control in LA and oriental hybrid lilies. Hort Technology $12: 426-431$.

Ranwala, N.K.D., A.P. Ranwala, and W.B. Miller. 2005. Effectiveness of plant growth regulator solutions after repeated dips. Hort Technology 15:551-553.

Whipker, B.E. and I. McCall. 2000. Response of potted sunflower cultivars to daminozide foliar sprays and paclobutrazol drenches. HortTechnology 10:209-211. 